\title{
Path Analysis on the Effects of Bio-psychosocial Factors and Calorie Intake in Blood Glucose Control in Patients with Type 2 Diabetes Mellitus
}

\author{
Isfaizah1,2), Bhisma Murti²), Dono Indarto3) \\ 1)Ngudi Waluyo University, Ungaran, Central Java \\ 2)Masters Program in Public Health, Sebelas Maret University, Surakarta \\ 3)Faculty of Medicine, Sebelas Maret University, Surakarta
}

\begin{abstract}
Background: Diabetes mellitus (DM) is a serious chronic disease with its tendency to deteriorate. The DM cases worldwide in 2015 was 415 million people and it is estimated to increase as many as 642 million cases in 2040. Indonesia ranked 7 in the world with 10 million cases of DM in 2015, about $90 \%$ of which were Type 2 Diabetes Mellitus. This study aimed to determine the effect of biopsychosocial factors and calorie intake on the blood glucose control in patients with Type 2 DM.

Subjects and Method: This was an analytic and observational study with case control design. This study was carried out at Internal Medicine Polyclinic, Department of Endocrinology, Dr. Moewardi Hospital, Surakarta, Central Java, from October to November 2016. A total sample of 135 cases of Type 2 DM were selected for this study by fixed disease sampling. As many as 106 of these study subjects at HbA1c $\geq 6.5 \%$ and 29 cases of Type $2 \mathrm{DM}$ had HbA1c $<6.5 \%$. The dependent variable was HbA1c level. The independent variables were educational level, family income, psychological stress, calorie intake, and Body Mass Index (BMI). The data were collected by a set of questionnaire. HbA1c was measured by High Performance Liquid Chromatography (HPLC), which was recorded in the medical record. Calorie intake was measured by 24 hour food recall. Psychological stress was measured by International Physical Activity Questionnaire (IPAQ). The data was analyzed by path analysis on STATA 13.

Results: Psychological stress $(b=0.99,95 \% \mathrm{CI}=0.07$ to $1.92, \mathrm{p}=0.034)$, calorie intake $(b=1.84$, $95 \% \mathrm{CI}=-0.24$ to $3.92, \mathrm{p}=0.083)$, and $\mathrm{BMI}(\mathrm{b}=1.15,95 \% \mathrm{CI}=0.22$ to $2.08, \mathrm{p}=0.016)$, had positive and statistically significant effect on HbA1c. Calorie intake increased BMI $(b=2.35,95 \% \mathrm{CI}=0.31$ to $4.39, \mathrm{p}=0.024)$, education decreased calorie intake $(\mathrm{b}=-2.26,95 \% \mathrm{CI}=-3.38$ to $-1.14, \mathrm{p}<0.001)$, and family income increased calorie intake $(b=1.23,95 \% \mathrm{CI}=0.26$ to $2.21, \mathrm{p}=0.013)$.

Conclusion: Calorie intake, BMI, psychologi stress, and family income are associated with increase in HbA1c level. Education decreases HbA1c level via decreased calorie intake. Type 2 DM patients need to pay attention to these biopsychosocial factors and calorie intake in order to control blood sugar.
\end{abstract}

Keywords: biopsychosocial factors, calorie intake, HbA1c

\section{Correspondence:}

Isfaizah. Ngudi WaluyoUniversity, Ungaran, Central Java. Email: is.faizah84@yahoo.com. Mobile: +6281228570003 .

\section{BACKGROUND}

Diabetes mellitus is a serious chronic disease with a tendency to deteriorate (Colberg et al., 2010; Bilous and Donelly, 2015). About 5-7\% of world population suffer from $\mathrm{DM}$ and in 2012 there were 21 million people with DM in the United States (ADA,
2012; CDC, 2014). In 2015 there were 415 million diabetic people worldwide and were estimated will be increasing to 642 million in 2040 (IDF, 2015). Based on an estimation there are 1.7 new DM cases each year (CDC, 2014). Indonesia ranked 7 in the world with 10 million cases of DM (IDF, 
2015 and will be increasing to 21.3 million in 2030 (ADA, 2012). DM prevalence in Indonesia in 2013 was $6.9 \%$ and $90 \%$ of it was type 2 diabetes mellitus. Surakarta was a city in Central Java with the highest type 2 DM prevalence, that was 22,534 cases (Health Ministry of the Republic of Indonesia, 2013).

Diabetes became the first of the leading cause of death in the world with 5 million people die each year, it means every 6 seconds there is 1 person die for diabetes (IDF, 2015). DM became the cause of death no. 7 in United States that was 69,071 and estimated as the $7^{\text {th }}$ of the world cause of death in 2030 (ADA, 2012). Blood glucose control on patients with diabetes is important to prevent the emergence of complication, both micro vascular and macro vascular (Perkeni, 2011; Bilous and Donelly, 2014). The achievement in controlling blood glucose level can be observed by monitoring the level of hemoglobin glycemic (HbA1c) (Farmer, 2009). HbA1c is a reflection of control on blood glucose of DM patients during 8-12 weeks which is better than observing urine and blood sugar concentration. Level of HbA1c $<6.5$ shows controlled glycemic index on diabetic patients and HbA1c $\geq 6.5 \%$ shows uncontrolled glycemic index (Bilous and Donelly, 2014).

Major key of type 2 diabetes mellitus management is diet and life style modification such as avoiding psychological stress. The major purposes of the management are to reduce the demand for production of endogenous insulin, to increase insulin sensitivity by reducing body weight for obese patient and to increase glycemic control (Lawn et al., 2009). Appropriate control on blood glucose level can reduce the risk factors of cardiovascular diseases which contribute to $70-80 \%$ of death as the result of type 2 diabetes (Bilous and Donelly, 2014).
About $80 \%$ of type 2 DM patients are proven enduring obesity or over weight (Bilous and Donelly, 2014). DM patients' blood glucose level escalates as much as 1.1 times on peripheral obesity and 1.6 times on central obesity although not significant (Mihardja, 2009). The increasing of IMT escalates the risk of insulin dependency as much as 1.77 in $25 \leq \mathrm{IMT} \leq 27.49$ to 3.57 in IMT $\geq 40$ and increasing death risk as much as $40 \%$ on overweight and $300 \%$ on obese patients (Gray et al., 2015). Sensitivity toward insulin on DM patients with obesity is decreasing so that blood glucose level in blood circulation increases.

Body weight loss is very important in blood glucose level control by reducing total calorie intake and/or increasing physical activities as well as energy expenditure. Body weight loss by $0.5^{-1} \mathrm{~kg}$ per week can increase glycemic control by limiting energy and diet on mono unsaturated fatty acid (MUFA) (Bilous and Donelly, 2014). Energy/ Calorie intake is related to the control of fasting blood glucose level of type $2 \mathrm{DM}$ patients. Insulin helps glucose gets into cells through metabolism process of some nutritions such carbohydrate, protein, fat that produce glucose and insulin help glucose gets into cells. The reduction of insulin receptor in DMT2 causes only small amount of glucose that can get into cell and big amount of free glucose in blood circulation that can generate hyperglycemia. Carbohydrate and fat intake is related to control of blood glucose level and protein protein intake is not related to the control of blood glucose level (Parutu, 2012). High content of carbohydrate and fat within food intake causes big amount of glucose can not be absorbed by cells then it initiates uncontrolled blood glucose level, whereas protein acts more as cell builder function of body which does not interfere in the control of blood glucose level (Almaitser, 2011). 
Deterioration of the disease and drug dependence trigger the emergence of psychological stress on DMT2. In stress condition the production of cortisol is increasing, insulin's function is obstructed and hepar will initiate gluconeognenesis so that glucose level is increasing. Continous stress generates lack of sensitivity towars insulin so that blood glucose level increases and metabolic syndrome also diabetic ketoacidosis (Mitra, 2008; Bilous and Donelly, 2014). Stress blockades body from releasing insulin hormone for DMT2 patients, thus initiate hyperglycemia and the increasing level of blood glucose (Izzati and Nirmala, 2015).

Control on blood glucose level is also influenced by education and family income. People with high level of education (>12 years) are likely to have healthier life behavior by controlling their diet compared to those with lower level of education. A person with high level of education is likely to get job opportunity that can improve family income. Patient with high level of education is easier in receiving therapy given by doctor to control glucose level. Family high income enables someone to buy a lot of food which is high in fat, whereas one with low income tends to buy food with high carbohydrate thus increases blood glucose level. High social economy increases blood glucose level as much as 1.3 times compared to lower social economy level, however it is statistically insignificant and there is no association between education and blood glucose level, however uncontrolled blood glucose level is likely to occur to patients with low level of education (Mihardja, 2009).

Examination on HbA1c becomes an indicator in the achievement of blood glucose level control on DMT2 patients. Therefore factors that are able to increase the level of HbA1c need to be investigated to be a guidance for preventing DMT2 secondary patients from emerging metabolic complication. A preliminary study in Dr. Moewardi Hospital found that the frequency of diabetes mellitus patients' visits in Internal Medicine Polyclinic, Department of Endocrinology every month are as many as 300400 cases with HbA1c conducted once every three months.

High prevalence of DM patients' visits turn into big challenge for health personnel to make patients to be self reliance by managing the determinats of blood glucose level control to reduce the risk of complication emergence on DM patients. Based on the elaboration above therefore it was important to conduct a study about the analysis on determinant pathway of blood glucose level control on DMT2 patients. The study was prognosis research whose result was expected to give contribution in deciding which determinant could give the most influence toward blood glucose control on DMT2 patients as a prevention step over diabetic complication.

\section{SUBJECTS AND METHOD}

This study used observational analytic design with case control approach. Data collection was conducted on October 17- November 25, 2016 in Internal Medicine Polyclinic, Department of Endocrinology. Dr. Moewardi Regional General Hospital Surakarta.Variables used in this study were education, family income, calorie intake, Body Mass Index, psychological stress, and $\mathrm{HbA}$ 1c level. Target population was the entire diabetes mellitus patients who were undergoing examination in Internal Medicine Polyclinic, Department of Endocrinology, Dr.Moewardi Hospital, Surakarta. 135 samples were selected using fixed disease sampling with comparison 1:4 between case group (HbA1c $<6.5 \%$ ) dan control group (HbA1c $\geq 6.5 \%$ ). Data collection techniques 
by using questionnaires, IPAQ, 24 hour food recall medical records. The data was analyzed by using path analysis with STATA 13.
RESULTS

1. Characteristics of Research Subjects

Table 1. Characteristics of research subjects based on age, family income, pscychological stress, calorie intake and BMI

\begin{tabular}{|c|c|c|c|c|c|c|c|}
\hline \multirow{2}{*}{$\begin{array}{l}\text { Characteristics of } \\
\text { Research Subjects }\end{array}$} & \multicolumn{3}{|c|}{ Control $($ HbA1c $<6.5 \%)$} & \multicolumn{3}{|c|}{ Case (HbA1c $\geq 6.5 \%)$} & \multirow[b]{2}{*}{ p } \\
\hline & Mean \pm SD & Min & Max & Mean + SD & Min & Max & \\
\hline Age(year) & $55.03 \pm 11.12$ & 32 & 83 & $55.75 \pm 8.28$ & 40 & 77 & 0.151 \\
\hline $\begin{array}{l}\text { Family Income } \\
\text { (million) }\end{array}$ & $3.18 \pm 3 \cdot 31$ & 0.6 & 15 & $2.97 \pm 2.59$ & 0.5 & 20 & 0.494 \\
\hline Psychological Stress & $64.76 \pm 9.99$ & 43 & 82 & $70.55 \pm 13.61$ & 43 & 110 & 0.014 \\
\hline Calorie Intake (\%RDA) & $65.97 \pm 13.52$ & 43 & 90 & $75.17 \pm 17.49$ & 45 & 110 & 0.016 \\
\hline BMI $\left(\mathrm{kg} / \mathrm{m}^{2}\right)$ & $24 \pm 3.42$ & 17 & 30 & $26.26 \pm 3.51$ & 19 & 37 & 0.002 \\
\hline
\end{tabular}

Tabel 1 shows that there is no characteristic differences on research subjects case group and control group ( $\mathrm{p}>0.05)$. There are characteristic differences on research subjects in case group amd control group over variables of psychological stress, calorie intake, $\mathrm{BMI}$, gender types, and education ( $\mathrm{p}<0.05)$. Mean of psychological stress in case group is higher $(70.55 \pm 13.61)$ than in control group $64.76 \pm 9.99)$. Mean of calorie intake in case group is higher $(75.17 \pm 17.49)$ than in control group $(65.97 \pm 13.52)$. Mean of BMI in case group is higher $(26.26 \pm 3.51)$ than in control group $(24 \pm 3.42)$ in which the means of BMI in both groups are in overweight category.

Table 2 shows that case group consists of more male (84.4\%) and elementary school backgrounded (92.3\%).

Table 2. Characteristics of research subjects based on gender types and education

\begin{tabular}{lccccc}
\hline \multicolumn{1}{c}{$\begin{array}{c}\text { Characteristics of } \\
\text { Research Subjects }\end{array}$} & \multicolumn{2}{c}{ Control (HbA1c <6.5\%) } & \multicolumn{2}{c}{ Case (HbA1c $\mathbf{2 6 . 5 \% )}$} & \multirow{2}{*}{$\mathbf{p}$} \\
\cline { 2 - 4 } Gender Types & $\mathbf{N}$ & $\mathbf{\%}$ & $\mathbf{N}$ & $\mathbf{\%}$ & \\
Female & 15 & 33.3 & 30 & 66.7 & \multirow{2}{*}{0.018} \\
Male & 14 & 15.6 & 76 & 84.4 & \\
Education & & & & & \\
Elementary & 5 & 7.7 & 60 & 92.3 & $<0.001$ \\
High & 24 & 34.3 & 46 & 65.7 & \\
\hline
\end{tabular}

\section{Bivariate Analysis}

Table 3. Chi Square analysis on the relationship between research subjects' characteristics and HbA1c level

\begin{tabular}{lcccc}
\hline \multirow{2}{*}{ Independent Variables } & \multirow{2}{*}{ OR } & \multicolumn{2}{c}{ 95\% CI } & \multirow{2}{*}{ p } \\
\cline { 3 - 4 } & & Lower Limit & Upper Limit & 0.030 \\
Pcychological Stress & 2.58 & 1.08 & 6.20 & 0.012 \\
Calorie Intake & 9.09 & 1.18 & 70.20 & 0.003 \\
Body Mass Index (BMI) & 3.72 & 1.54 & 9.01 & $<0.001$ \\
Individual Education & 0.16 & 0.06 & 0.45 & 0.520 \\
Family Income & 1.31 & 0.57 & 3.02 & \\
\hline
\end{tabular}

Table 3 shows all variables are positively related in controlling DMT2 patients' blood glucose level. Psychological stress, calorie intake, BMI and education are related with 
HbAic level and statistically significant ( $\mathrm{p}<0.05$ ), whereas family income is related to HbA1c level but statistically insignificant ( $>$ >.05). Food intake is the most correlated in the increasing level of HbA1c as much as 9.09 times and education is the least correlated in the increasing level of HbA1c.

\section{Pathway Analysis}

Table 4 shows that pathway the analysis model is already in accordance with log likelihood $=-186.40, \mathrm{AIC}=390.80$ and $\mathrm{BIC}=$ 416.95. Normal calorie intake has logodd HbA1c as much as 1.84 higher compared to less calorie intake yet it is not statistically significant $(b=1.84 ; 95 \% \mathrm{CI}=-0.24$ to 3.92 ; $\mathrm{p}=0.083$ ), over BMI has logodd HbA1c as much as 1.15 higher compared to normal BMI and statistically significant $(b=1.15$;
95\% CI= 0.22 to 2.08; $\mathrm{p}=0.016$ ), and moderate psychological stress has logodd $\mathrm{HbA}$ $1 \mathrm{c}$ as much as 0.1 higher compared to mild psychological stress and statistically significant $(b=0.99 ; 95 \% \mathrm{CI}=0.07$ to $1.92 ; \mathrm{p}=$ o.034). Normal calorie intake has BMI logodd as much as 2.35 higher compared to less calorie intake and statistically significant $(b=2.35 ; 95 \% \mathrm{CI}=0.31$ to $4.39 ; \mathrm{p}=$ o.024). High income has calorie intake logodd as much as 1.23 higher compared to insufficient family income and statistically significant $(b=1.23 ; 95 \% \mathrm{CI}=0.26$ to 2.21 ; $\mathrm{p}=0.013$, ). High education has calorie intake 3.38 lower than elementary education and statistically significant $(b=-3.38 ; 95 \%$ $\mathrm{CI}=-3.38$ to $1.14 ; \mathrm{p}<0.001)$.

Table 4. Pathway analysis of biopsychosocial and food intake with blood glucose level on Patients of Diabetes Mellitus Type 2

\begin{tabular}{|c|c|c|c|c|}
\hline \multirow{2}{*}{$\begin{array}{l}\text { Assocation between dependent and } \\
\text { independent variables }\end{array}$} & \multirow{2}{*}{$\begin{array}{l}\text { Path- } \\
\text { Coeff }\end{array}$} & \multicolumn{2}{|c|}{$95 \%$ CI } & \multirow[t]{2}{*}{$\mathbf{p}$} \\
\hline & & Lower Limit & Upper Limit & \\
\hline \multicolumn{5}{|l|}{ Direct } \\
\hline Calorie Intake (Normal) & 1.84 & -0.24 & 3.92 & 0.083 \\
\hline Body Mass Index/ BMI (over) & 1.15 & 0.22 & 2.08 & 0.016 \\
\hline Psychological Stress & & 07 & $0 ?$ & \\
\hline \multirow{2}{*}{\multicolumn{5}{|c|}{ Indirect }} \\
\hline & & & & \\
\hline \multicolumn{5}{|l|}{ Body Mass Index } \\
\hline Calorie Intake (Normal) & 2.35 & 0.32 & 4.39 & 0.024 \\
\hline \multicolumn{5}{|l|}{ Indirect } \\
\hline \multicolumn{5}{|l|}{ Calorie Intake $\leftarrow$} \\
\hline Family Income (High) & 1.23 & 0.26 & 2.21 & 0.013 \\
\hline Education (High) & -2.26 & -.3 .38 & -1.14 & $<0.001$ \\
\hline \multicolumn{5}{|l|}{$\mathrm{N}$ Observation $=135$} \\
\hline \multicolumn{5}{|l|}{ Log likelihood =-186.40 } \\
\hline $\mathrm{AIC}=390.80$ & Inform & on : & & \\
\hline $\mathrm{BIC}=416.95$ & $\leftarrow=\mathrm{C}$ & anected & & \\
\hline
\end{tabular}

\section{DISCUSSION}

The research tested hypothesis on biopsychosocial factors and calorie intake in blood glucose level control of DMT2 patients. Uncontrolled DMT2 patients (HbA1c $\geq 6.5 \%)$ possessed higher psychological stress, calorie intake, and BMI compared to controlled
DMT2 patients (HbA1c <6.5\%). Meanwhile the education level of uncontrolled patients seemed to be lower than controlled DMT2 patients. Most of uncontrolled DMT2 patients were male. Control of blood glucose level on DMT2 patients occurred because of the increasing calorie intake, BMI, psycho- 
logical stress. High calorie intake was influenced by the low education level and high family income.

Diet and life style modification became major key in controlling blood glucose level of DMT2 patients (Bilorus, dan Donelly, 2014). The result of the study showed that there was a positive association between calorie intake and HbA1c level. Normal calorie intake with HbA1c level was 1.84, however it was statistically insignificant $(\mathrm{p}=0.083)$. Calorie intakes on both groups in this study were different, in which the calorie intake of case group was much higher than control group's. Mean of calorie intakes on both groups was below Recommended Dietary Allowance (RDA) which was the result of patients' awareness in managing their daily diet therefore the lack of comparison with over calorie intake made the study result was insignificant. Energy/calorie is obtained from metabolism process of some nutritions such as carbohydrate, protein, and fat that are sourced from food which is eaten every day and broken down into glucose with the help of insulin. On DMT2 patients there is a disruption of insulin secretion or disruption in insulin sensitivity, so that lots of glucose can not be transformed into energy and most glucose circulates in the blood, causes uncontrolled level of blood glucose on DMT2 patients which can be observed from the increasing level of HbA1c. High calorie ingestion will increase the level of HbAic and statistically significant (Parutu, 2012).

Calorie intake interfere indirectly in glucose control through BMI. Normal calorie intake increases Body Mass Index by 2.35 and statistically significant $(\mathrm{p}=0.024)$. Reduction of calorie intake aims to attain ideal BMI so that blood glucose level turns into under control. Reduction of total calorie intake need to be conducted to lower down and attain ideal BMI. The gradual re- duction of body weight by $0.5-1 \mathrm{~kg}$ per week and at least $4 \mathrm{~kg}$ is able to soothe hyperglycemia. The reduction of body weight can be attained by cutting carbohydrate intake, high monounsaturated fatty acid (MUFA) diet as well as energy release restriction (Bilorus and Donelly, 2014).

Education and family income were related to calorie intake, in which high education on DMT2 patients is able to reduce calorie intake as much as 2.25 compared to lower education and statistically reliable $(\mathrm{p}<0.001)$. DMT2 patients with high level of education possesses better knowledge and obedience toward diet, exercise, takeing/ injecting diabetic medicine compared to those with lower level of education, therefore it is likely to control daily calorie intake (Miharja, 2009; Parutu, 2012).

Most of research subjects with high level of education held less calorie intake $(<90 \% \mathrm{RDA})$ as much as 92.8. It is because respondents with high education were likely to have sufficient knowledge about their disease and to comply with doctors' suggestion (Aliasgharzadeh et al., 2006). In addition to education calorie intake was also interfered by family income. Family income was associated with calorie intake and statistically significant $(\mathrm{p}=0.013)$. High family income increased the calorie intake by 1.23 times of low family income. Family income of controlled DM patients was much higher than uncontrolled DM patients' family income and categorized as high family income. High family income would increase purchasing power thus would increase total calorie intake whereas low family income was likely to fulfill primary needs which were higher in calorie than nutrition (vegetables and fruits intake). Furthermore, low family income reduce the opportunity to do physical exercises compared to high family income. It caused both high family income and low family income held influences in 
theincreasing of calorieintake(Majgi, 2012). It would generate poor glucose control on patients of diabetes mellitus type 2 with low income.

Calorie intake which keep on increasing on DMT2 will increase the amount of glucose which is stored in a form of fat. It can be observed from the growing bady weight and Body Mass Index. Around 80\% DM2 patients are proven to endure obesity or over weight and the risk of diabetes progressively increases along with the improvement of nutritional status (BMI). The risk of diabetes will increase by $80 \%$ during 10 years on those with BMI more than 35 $\mathrm{kg} / \mathrm{m} 2$ compared to those with BMI less than 22kg/m2 (Bilous and Donelly, 2014).

The study shows that there was a direct association between BMI with $\mathrm{HbA}$ $1 c$, in which BMI increasedHbA1c level and statistically significant $(\mathrm{p}=0.016)$. Over BMI on DMT2 patients increased HbA1c level 1.1 5 times higher compared to normal BMI. It was enabled by the characteristics difference of respondents on case and control groups $(\mathrm{p}<0.05)$, therefore it was possible for the occurrence of other variables that influence HbA1c level. Mean of BMI on case group was way higher than control group's and it was included in overweight category. Most of DMT2 patients possess over BMI, in which on DMT2 there is a problem in insulin sensitivity, therefore blood glucose level control is determined more on the activating of insulin receptor by doing diet and physical activity/ exercise as well as quit smoking (Bilous and Donelly, 2014). BMI reduction is very important to lower down the risk factor of cardiovascular diseases (CVD) such as hyperlipidemia, hypertension that contribute toward $70-80 \%$ of deaths as the result of DMT2.

Logue et al (2011) state that there is significant relationship between age and Body Mass Index (BMI) on female DMT2 patients compared to male. Women are likely to have adipose fat tissue and over belly fat (central obesity) compared to men, therefore the reduction of insulin sensitivity is greater happen to women that generates uncontrolled blood glucose level. Mean of fat on female was $26.9 \%$ of total weight and on male was only $14.7 \%$ of total male body weight. Excessive fat on women is stored in belly, chest, and upper body parts. High level of body fat generates increasing BMI on women that affects poor control on blood glucose level.

BMI is closely related in increasing blood glucose level on women compared to men. It happens since men are likely to have more muscle as the result of their activities and women hold more fat. Skeletal muscle will activate adiponectin peptide hormone to activate Activated Protein Kinase (AMPK) to suppress acetyl CoA Carboxylase (ACC) from synthesis of malonyl-CoA for bio synthesis of fatty acid in liver. AMPK activation also increases glucose and fatty acid releases from blood bio synthesis within liver metabolism. HbA1c level is increasing by $18 \%$ on overweight with $\mathrm{HbA1c} \geq 7-8 \mathrm{gr} \%(\mathrm{OR}=1.18 ; 95 \% \mathrm{CI}=$ 1.13 to 1.22 ), increasing by $15 \%$ on $\mathrm{HbA1c}$ $\geq 8-9$ gr\% (OR=1.15; 95\% $\mathrm{CI}=1.01$ to 1.21$)$, increasing by $16 \%$ on HbA1c $\geq 9$ gr\% (OR= 1.16; $95 \% \mathrm{CI}=1.01$ to 1.21 ) (Innocent et al., 2013).

Body function which is declining and continuous medical treatment lead DMT2 patients to be stress-prone. The study result showed that psychological stress was directly related to blood glucose level control. Moderate psychological stress would increase the level of HBA1c by 1.24 times higher compared to mild stress, however it was statistically unreliable $(p=0.056)$. It was possibly because of the different psychological stress characteristics between respondents on case and control group that 
it was possible for the occurrence of other factors outside the stress that was influenced by blood glucose control. In this study almost most of the patients who made repeated visits in Internal Medicine Polyclinic of Dr. Moewardi Regional General Hospital, Surakarta were regular patients who already understood and embraced their sickness, patients tend to let go and accepted their current condition. Respondents who were frustrated with their condition was due to their inability to do daily activities by themselves, dependency over treatment, deteriorating disease, and on male patients were likely endure libido decreasing that generated lack of confidencetoward their spouses and it triggered psychological stress. Patients of lengthy type 2 DM (>5 years) tend to be over in blood glucose level and uncontrolled, that may cause micro vascular complication such as erection dysfunction. Male patients are likely to be concerned more on impotence problems compared to blindness and amputation. Impotence causes stress to diabetes mellitus type 2 patients and leads to uncontrolled blood glucose(Harahap, 2006).

Stress on DMT2 patients can cause problems in controlling blood glucose level because of the increasing cortisol that blockade insulin (Mitra, 2008). The study was not in accordance with Nugroho dan Purwanti (2010) who states that there is an association between psychological stress and the increasing of blood glucose level. Continually high concentration of cortisol is a predisposition factor to the emergence of metabolic complication on DMT2 patients (Anagnostis et al., 2009; Kan PH et al., 2014). During stress condition hypothalamus will send signal to adrenal glands to produce catecholamine, glucagon, glucocorticoid, $\beta$-endorphin hormones and stimulates pituitary gland to produce growth hormone and release it into blood circulating system. The increasing of hormone will stimulate heartbeats, respiration, blood pressure, and metabolism. Over production of cortisol stimulates liver to conduct gluconeogenesis and obstruct insulin function thus generates the increasing of blood glucose. Meanwhile glucose that is produced in liver is not used for body metabolism consequently there will be glucose level escalation in blood. As the result, body accumulates a lot more energy, glucose and fat in cells that generate uncontrolled blood glucose on DMT2 patients (Mitra, 2008).

The study was not in accordance with Izzati and Nirmala (2015) who stated that there was an association between stress level and blood glucose level of DM patients in the area of Rasimah Ahmad Municipal Healthcare Center Bukit Tinggi and statistically significant $(\mathrm{p}=0.017)$. The study revealed that severe stress boosted by 9 times the risk to endure increased blood glucose level compared to moderate stress. Someone who is severely stressed will produce a lot more cortisol as the result it reduce body sensitivity toward insulin. Cortisol is an opponent of insulin and makes glucose to be a lot more difficult to get into cells so that it generates increasing glucose in blood circulation (Wade and Tavris, 2007). Stress makes people lose their self control, stimulates to eat snack and food that is comforting outside regular meal time by eating their favorite food such as chocolate, sweets, ice cream, between meals. Moreover, someone who is anxious is likely to do less activities and forget to check blood glucose level. It leads to increasing blood sugar level on DMT2 patients and poor blood glucose control (Mitra, 2008).

The higher calorie intake, BMI and psychological stress will increase the level of HbA1c. Calorie intake increases BMI, whereas family income increase calorie intake. The higher education level of DMT2 
Indonesian Journal of Medicine (2016), 1(2): 90-99

https://doi.org/10.26911/theijmed.2016.01.02.02

patients the more decreasing daily calorie intake will be.

\section{REFERENCE}

ADA (2012). Statistic about Diabetes: Overall Numbers, Diabetes and Prediabetes.http://www.diabetes.org/diabetesb asics/statistics/?referrer=https://ww w.google.co.id/.

Aliasgharzadeh A, Mobasseri M, Adib M (2006). Adherence to Management Plant For Diabetes in Type 2 Diabetic Patients, Abstract Book $13^{\text {th }}$ Asia Oceania Congress of Endocrinology 162.

Almatsier S (2011). Prinsip Dasar Ilmu Gizi. Jakarta: Gramedia Pustaka Utama.

Anagnostis P, Athyros VG, Tziomalos K, Karagiannis A, Mikhailidis DP (2009). Clinikal Review: The Pathogenetic Role of Cortisol in The Metabolic Syndrome: a Hyputhesis. J Clin Endocrinol Metab 94(8): 2692-2701.

Billous R, Donelly R (2014). Buku Pegangan Diabetes Edisi Ke 4. Jakarta: Bumi Medika.

CDC (2014). National Diabetes Statistics Report 2014. https://www.cdc.gov/diabetes/pubs/statsreport14/nationaldiabetes-report-web.pdf.

Colberg SR, Sigal RJ, Fernhall B, Regensteiner JG, Blissmer BJ, Rubin RR, Taber LC,AlbrightAL, Braun B (2010). Exercise and Type 2 Diabetes: The American College of Sports Medicine and The American Diabetes Association: Joint Position Statement. Diabetes Care 33: e147-e167.

Farmer (2009). Self-monitoring of Blood glucose for people with type 2 diabetes: the need for better understanding. Diabetes Voice 54.

Gray N, Picone G, Sloan F, Yashkin A (2015). The Relationship between BMI and Onset of Diabtes Mellitus and its
Complications. South Med J 108 (1): 29-36.

Harahap R (2006). Disfungsi Seksual pada Penderita Diabetes Melitus Pria. Majalah Kedokteran 39 (3).

Izzati W, Nirmala (2015). Hubungan Tingkat Stres dengan Peningkatan Kadar Gula Darah pada Pasien Diabetes Melitus di Wilayah Kerja Puskesmas Perkotaan Rasimah Ahmad Bukittinggi Tahun 2015. Karya Tulis Ilmiah. Prodi DIII Keperawatan STIKES YARSI SUMBAR Bukittinggi.

IDF (2015). Diabetes Atlas. www.idf.org/eatlas.diakses pada tanggal 12 Juli 2016 pukul 11.05.

Jawad M, Lee JT, Millet C (2014). The Relationship Between Waterpipe and Cigarette Smoking in Low and Middle Income Countries: Cross-Sectional Analysis of the Global Adult Tobacco Survey. PLos ONE 9 (3): e93097.

Kann PH, Muntel M, Hadji P, Daniel H, Flache S, Nyarango P, Wilhelm A (2014). Alterations of Cortisol Homeostasis May Link Changes of the Sociocultural Environment to an Increased Diabetes and Metabolic Risk in Developing Countries: A Prospective Diagnostic Study Performed in Cooperation With the Ovahimba People of the Kunene Region/ Northwestern Namibia. J Clin Endocrinol Metab 100(3): E482-E486; doi:10.12 10/jc.2014-2625.ISSN Print 0021-972 X ISSN Online 1945-7197.

Kemenkes RI (2013). Diabates Melitus Penyebab Kematian Nomor 6 di Dunia: Kemenkes Tawarkan Solusi Cerdik Melalui Posbind. http://www. depkes. go.id/article/view/2383/diabetes-melitus-penyebab-kematian-nomor-6-di -dunia-kemenkes-tawarkan-solusicerdik-melalui-pos bindu.html. 
Lawn S, Battersby M, Harvey P, Pols R, Ackland A (2009). A Behavioural Therapy Approach to Self-Management: The Flinders Program.

Logue L, Walker JJ, Colhoun H, Leese GP, Lindsay RS, Mcknight JA, Morris AD, Pearson D, Petrie JR, Philip S, Wild S, Sattar N (2011). Do men Develop type 2 Diabetes at Lower Body Mass Indices than Women?. Diabetologia 54 (12): 3003-3006.

Majgi SM, Soudarssanane B, Roy G, Das AK (2012). Risk Factors of Diabetes Melitus in Rural Puducherry.Online Journal of Health and Allied Sciences 11 (1): 4 .

Miharja L (2009). Faktors Associated with Blood Glucose Control in Patient with Diabetes Mellitus in Urban Indonesia. Majalah Kedokteran Indonesia 59:9.
Mitra A (2008). Diabetes and Stress. A Review.Ethmo-med 2 (2): 131-135.

Nugroho SA, Purwati (2010). Hubungan antara tingkat stres terhadap kadar gula darah penderita diabetes melitus di Wilayah Kerja Puskesmas Sukoharjo I Kabupaten Sukoharjo. Skripsi. Fakultas Ilmu Kesehatan Masyarakat Universitas Muhammadiyah Surakarta.

Paruntu OL (2012). Asupan Gizi dengan Pengendalian Diabetes pada Diabetesi Tipe II Rawat Jalan di BLU Prof.Dr. R.D.Kandou Manado. Gizido 4: 1.

Perkeni(2011). Konsesnsus Pengelolaan dan pencegahan Diabetes Melitus Tipe 2 di Indonesia.https://drive.google.com/fi le/d/oBzXy8chsYGc1dohOVUJUNoU tbVU/view. 